\title{
What Happened to the Economy in the First Half of 1980?
}

\author{
ALBERT E. BURGER
}

$\mathbf{T}_{\mathrm{H}}$ HE U.S. economy was subjected to severe strains during the first half of 1980 . Beginning in the fall of 1979, the growth of the money stock (M1B) slowed substantially and then declined sharply for three months in early 1980. The price of oil was raised substantially late in 1979 , and a major selective credit restraint program was introduced early in 1980. Prices rose sharply, and the long-expected recession occurred with severe effects on specific sectors of the economy, such as autos and housing. In the space of a few months, interest rates soared to record high levels and then plunged as quickly. As market interest rates climbed above Regulation $Q$ ceiling rates and rates set by state usury laws, financial institutions experienced difficulties in holding and acquiring funds and, hence, in performing their traditional roles in the financial system.

When major economic developments occur so rapidly, it is difficult to isolate the basic forces that are driving the economy. Explanations that seem reasonable one week are apparently negated by developments that occur a few weeks later. Now that the first half of 1980 is history, it is possible to present a coherent explanation of economic developments that arose during this period, especially in regard to the role of monetary actions.
Such an explanation requires more than a simple listing of economic events; it demands a framework of analysis that ties diverse economic events together and relates them to policy actions. The first section of this article presents such a framework.

\section{A FRAMEWORK OF ANALYSIS}

The analytical framework presented in this section relates inflation and changes in the growth of real output to monetary developments. To explain economic events that have occurred thus far in 1980 as simply as possible, the analysis is presented in sum. mary form and various relationships are illustrated through the use of charts and tables.

\section{Money and Inflation}

Inflation refers to persistent increases in prices. Prices denote the rate of exchange between money and various goods and services. Consequently, an analysis of inflation must consider the rate of growth of (1) the amount of money available to the public, (2) the amount of money the public is willing to hold relative to total spending, and (3) the amount of goods and services available to the public (real output). The long-run or trend growth of real out- 


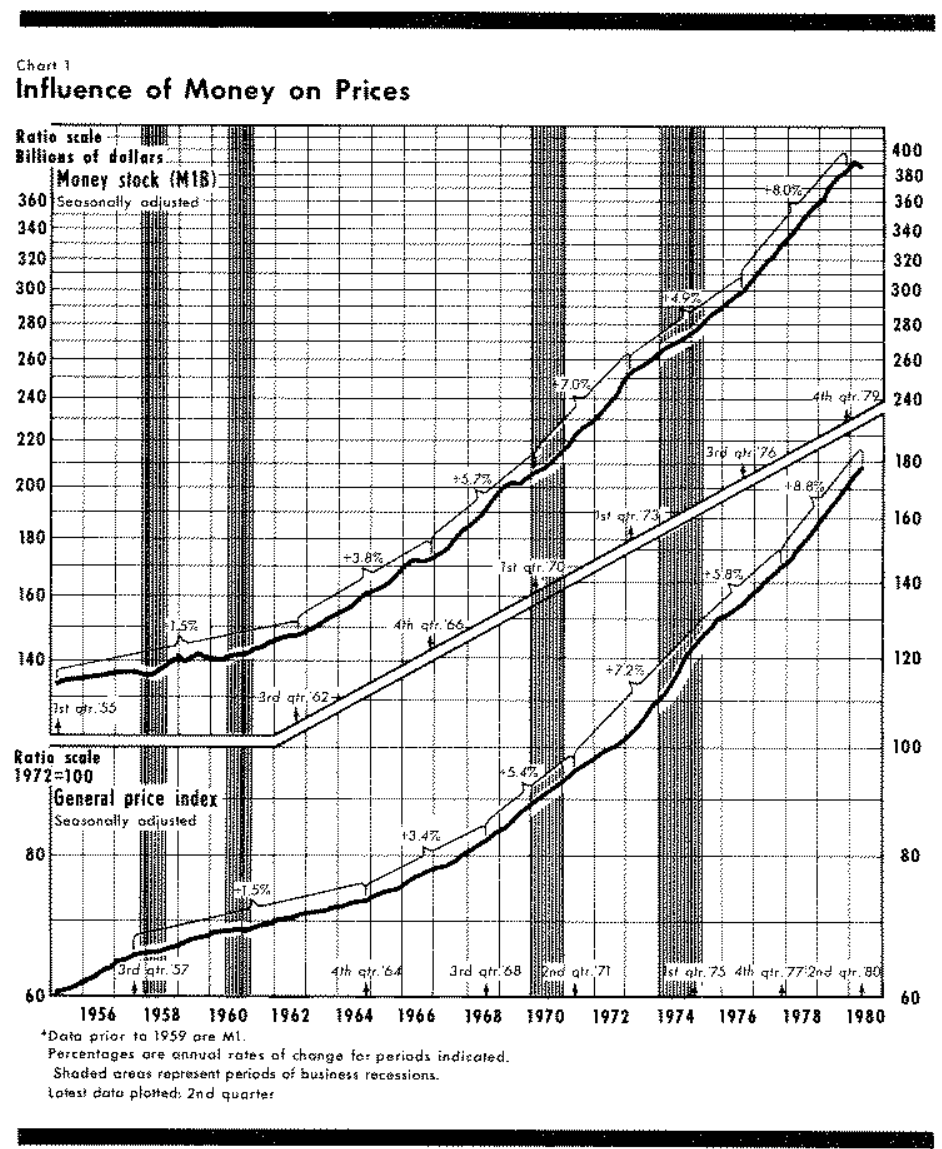

put is determined by such factors as the growth and quality of the labor force, capital formation, technology, availability of natural resources, etc. This trend rate of growth in real output is essentially unaffected by monetary developments. ${ }^{1}$

The trend rate of price increases, for a given growth of real output, depends on the rate of growth of the money stock and the willingness of the public to hold money relative to growth in total spending. Consequently, inflation is frequently referred to as a mone tary phenomenon. If the rate of growth of the stock of money exceeds the rate at which individuals are willing to increase their holdings of money, they will attempt to eliminate their excess money balances, and prices will be driven up. In the United States, the longurun or persistent rate of increase in prices has approximated the trend rate of growth of the money stock, as shown in chart 1 . When the money stock increased at less than a 2 percent rate for a

\footnotetext{
1As the rate of inflation has risen rapidly, relative to past U.S. experience, the complete independence of the trend growth of real output and growth of money has been called into question. See Keith M. Carlson, "Money, Inflation, and Economic Growth: Some Updated Reduced Form Results and Their Implications," this Review (April 1980), pp. 13-19.
}

prolonged period, as from the middle 1950s to the early 1960s, inflation rose at less than a 2 percent rate. When the trend growth of money moved upward, so did inflation. Since the early 1960s, the longrun average rate of increase in prices has slowed only once-from early 1973 through 1977 - when the trend rate of money growth also slowed.

Viewing inflation in this long-term monetary context provides a consistent explanation of the average rate of inflation over the past nine years. From IV $/ 70$ IV/79, money grew on average at a 6.7 percent annual rate and inflation averaged 7 percent, as shown in table 1.

However, examination of the data in table 1 reveals sub-periods within the last nine years in which there were wide differences between the growth of money and inflation, including several periods in which money growth slowed substantially while inflation accelerated. These circumstances can be explained within the framework of analysis by showing (1) connections between short-run variations in the growth of money and the growth in real output, and (2) the effects of supply-side shocks on the level of prices. 


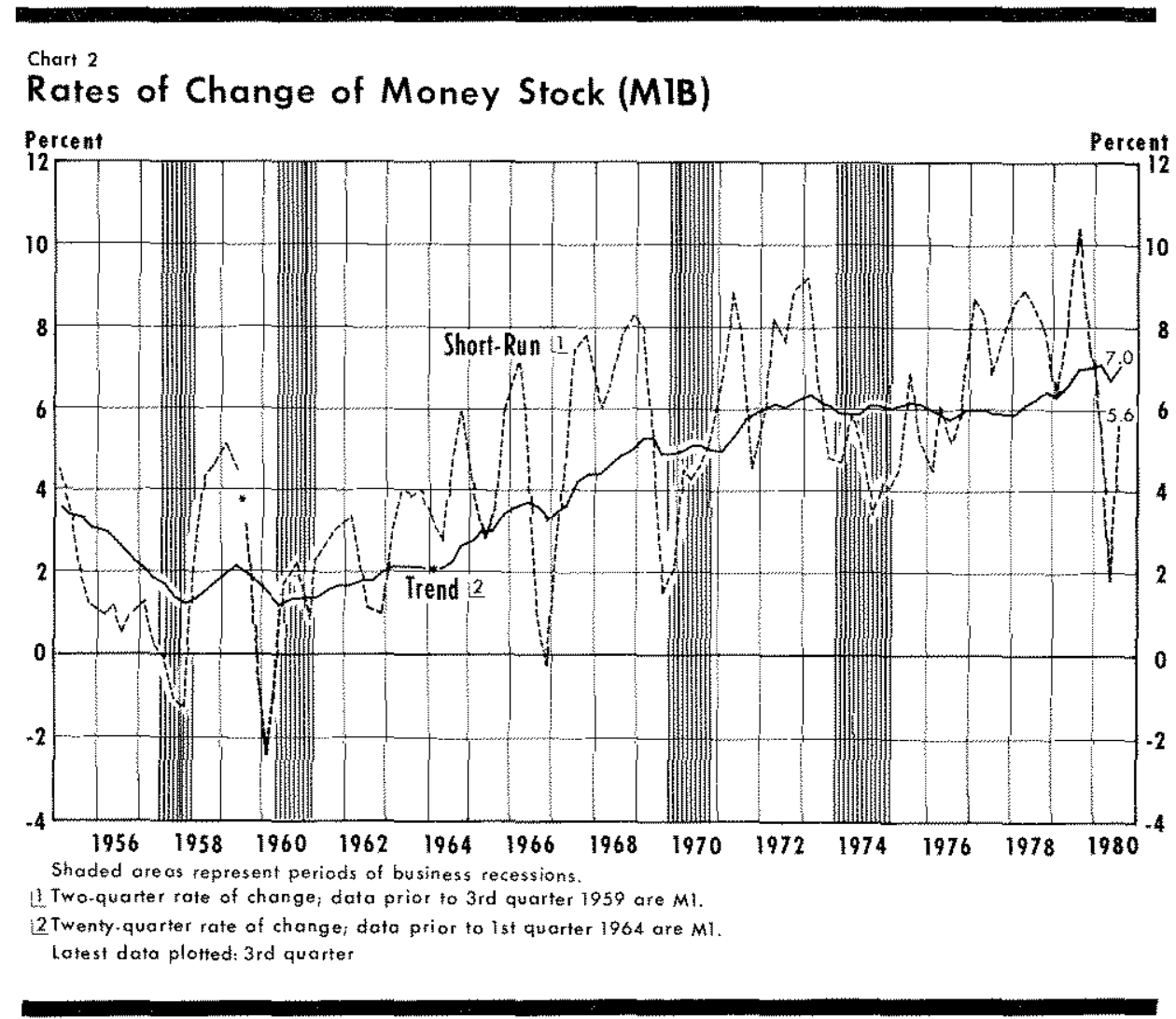

Table 1

\section{Growth Rates of Money, Prices, and Real Output}

\begin{tabular}{|c|c|c|c|}
\hline Period & Money & Prices & $\begin{array}{l}\text { Real } \\
\text { olitput }\end{array}$ \\
\hline $1 / 70-1 / 73$ & $77 \%$ & $46 \%$ & $63 \%$ \\
\hline $1173-1174$ & 5.3 & 82 & 00 \\
\hline $1 / 4,175$ & 3.7 & 11.6 & 4.8 \\
\hline $1775-11 / 76$ & 55 & 54 & 59 \\
\hline $11 / 76-1 \mathrm{~N} / 78$ & 81 & 71 & 50 \\
\hline $1178-11 / 79$ & 8.5 & 91 & 0.6 \\
\hline $11 / 79,1 \mathrm{l} / 80$ & 2.9 & 9.4 & 26 \\
\hline $11179,1 / 80$ & 86 & 89 & 16 \\
\hline $1 / 80-1180$ & $-2,3$ & 10.6 & 90 \\
\hline $1 \mathrm{~V} / 70,1 \mathrm{~V} / 79$ & 6.7 & 70 & 33 \\
\hline
\end{tabular}

\section{Money and Real Output}

Although changes in the trend growth rate of money have virtually no effect on the trend growth of real output, short-run fluctuations in money growth do affect the short-run growth in real output. Pro- ducers do not immediately adjust prices to changes in the demand for goods and services that occur when the public attempts to adjust the amount of money held to the amount they desire to hold, given income and interest rates. Consequently, real output bears the initial brunt of the effects of the public's adjustments to a substantial change in the rate of growth of their money holdings.

Fluctuations in short-run money growth relative to trend money growth offer an abridged way of illustrating the severity of short-run monetary developments. $^{2}$ Chart 2 depicts two-quarter growth rates of money relative to a 20 -quarter trend. In the past, each time short-run money growth has fallen substantially below trend, output has slowed substantially, many times by an amount large enough to classify that period as a recession. ${ }^{3}$ In addition, the acceleration of short-run money growth typically provides a temporary impetus to real output growth that moves it above trend. For example, the short-run growth of

2 For an alternative way of representing monetary acceleration and deceleration, see William Poole, "The Relationship of Monetary Deceleration to Business Cycle Peaks: Another Look at the Evidence," Journal of Finance (June 1975), pp. 697-712.

Although not classifed as a full recession, the $1966+67$ period has frequently been referred to as a mini-recession. 
money was substantially above trend in 1977 and 1978 , as shown in chart 2. Table 1 indicates that real output grew by more than 5 percent during this period, substantially more than any prevailing estimates of the rate that could be maintained over a prolonged period of time. The growth of real output eventually had to return to the rate dictated by labor force growth, capital formation, etc, even if the monetary stimulus remained very strong.

\section{Monetary Policy Objectives and Growth of Money}

The primary long-run objectives of monetary policy are to avoid inflation and to encourage growth of real output. When inflation is low and real output is growing at what policymakers consider "an acceptable rate," these two objectives do not conflict. When real output growth is "too low" or inflation "too high," however, these two goals can conflict especially in the short run.

Real output growth can be temporarily accelerated above its trend rate by increasing the degree of monetary stimulus. However, if such a policy action is maintained, greater inflation results, which violates the other objective of monetary policy. On the other hand, reducing inflation that is the result of past policy actions (the monetary rate of inflation) is a longterm proposition requiring a reduction in the trend growth of money. If policy actions sharply reduce the growth of money in the short term, inflation is not affected, but the growth of real output will decline and the economy may slide into a recession. Consequently, at times when either of the major policy goals is not being met, the Federal Reserve must design its policy actions carefully and enforce them consistently to avoid violating the other policy goal.

\section{Supply-Side Effects, Real Output, and Inflation}

Growth of real output can drop suddenly and temporarily for reasons unrelated to decelerated money growth. Supply-side shocks, such as droughts, floods, reduction in the supply of a basic factor input such as oil, or an unexpected sharp rise in the relative price of a factor input, can cause sharp declines in real output. ${ }^{4}$ If money continues to grow at the same rate

\footnotetext{
4See Robert H. Rasche and John A. Tatom, "The Effects of the New Energy Regime and Economic Capacity, Production, and Prices," this Review (May 1977), pp. 2-12.
}

that prevailed prior to the supply shock, prices must rise. As the level of prices adjusts upward, inflation soars above the rate dictated by the trend rate of monetary expansion. However, unless the rate of growth of money also accelerates, inflation returns to the rate dictated by the trend growth of money, after the level of prices has adjusted.

Since 1972, the major supply-side shocks affecting the economy have resulted from developments in the energy industry. The periodic sharp increases in energy prices relative to output prices have reduced the productivity of the existing capital stock and labor and, hence, have reduced output. The consequences have been periodic sharp rises in the level of prices and reductions in the growth of real output, as occurred in 1973-74 and $1979 .^{5}$

\section{Monetary Policy Objectives and Supply-Side Effects}

Since supply-side effects definitely influence the measured growth of real output and inflation, they can obscure the ongoing effects of monetary developments on these variables. During the transition period in which the economy adjusts to supply-side shocks, it is important to keep in mind what monetary policy actions can and cannot do in relation to real output and inflation. Monetary policy actions can create more money; they cannot create more oil, grain, cattle, or any other real good or service. The sharp rise in the level of prices accompanying supplyside shocks simply reflects the way a market economy eliminates the shortage of any good. The surge in prices does not represent a rise in the lasting rate of inflation; that rate is still being determined by the cumulative effects of past policy actions on the trend growth of money. Once the level adjustment of prices is completed, the measured rate of inflation slows. This pattern of price movements does not reflect monetary policy actions, but simply indicates that the rate of increase of prices is returning to the rate dictated by monetary expansion. ${ }^{6}$ Attempts to offset the effects of supply-side shocks on real output by sharply accelerating the growth of money only cause prices to rise further.

\footnotetext{
${ }^{5}$ See Denis S. Kamosky, "The Link Between Money and Prices - 1971-76," this Review (June 1976), pp. 17-23.
}

"See Albert E. Burger, "Is Inflation All Due to Money?" this Review (December 1978), pp. 8-12. 

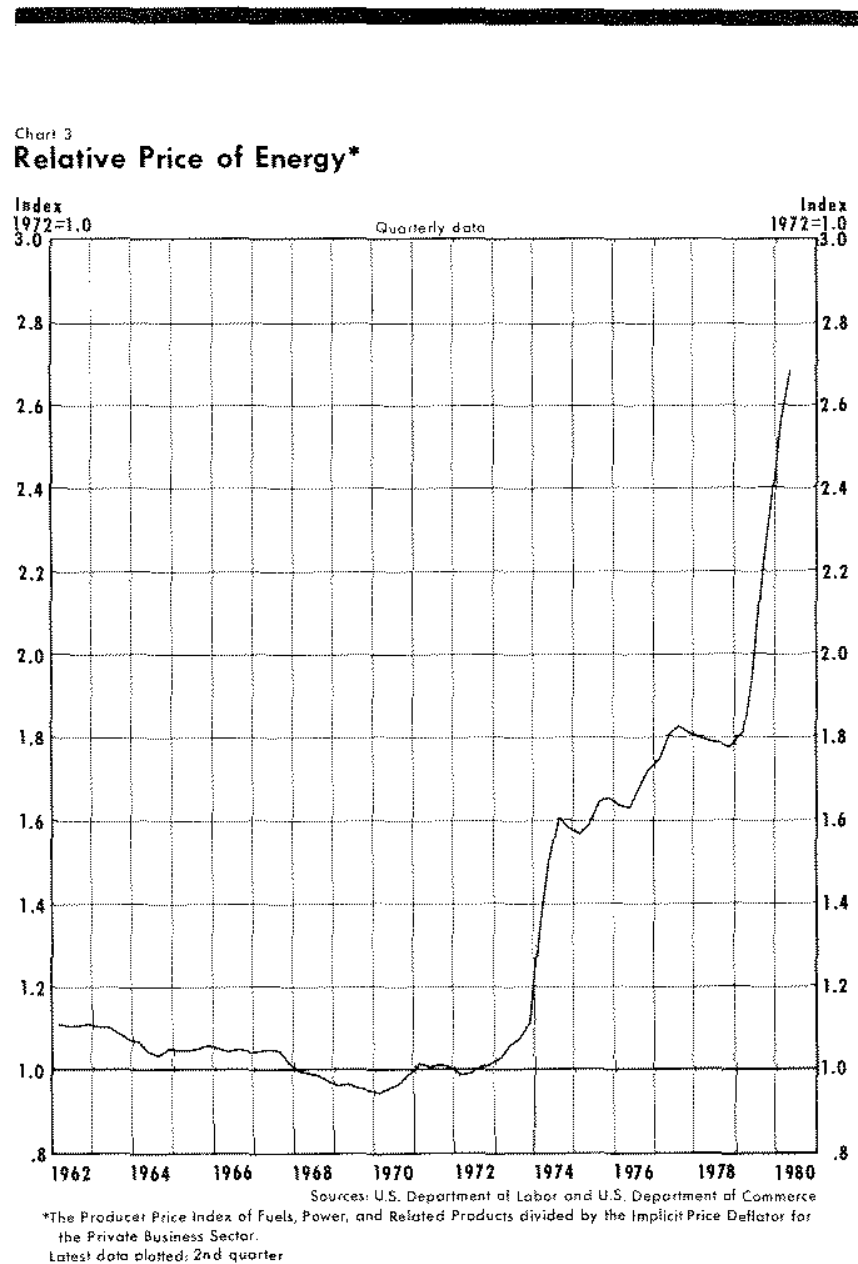

\section{ANALYSIS OF THE FIRST HALF OF 1980}

The two major forces affecting the economy in the first half of 1980 were a major change in the growth of the money stock and a continuation of the supplyside effects of increased energy prices. These two forces both operated to depress real output growth. The monetary developments had little initial effect on reducing the basic monetary rate of inflation, while developments in the energy markets served to raise the level of prices and push the measured rate of price increases considerably above the rate of inflation dictated by the long-term growth in money.

\section{Supply-Side Effects}

In early 1980 , as in 1979 , real output growth contimued to be restrained by the large ongoing rise in the relative price of energy. The composite refiner acquisition cost of crude oil rose from $\$ 12,93$ per barrel in December 1978 to $\$ 27.85$ per barrel in May 1980. This increase is reflected in the sharp rise in energy prices relative to output prices, as shown in chart 3. This rise in the relative price of energy, which was approximately the same as that in 1973-74, was the primary cause of the drop in real output growth from 4.8 percent in 1978 to 1 percent in $1979 .^{7}$ Its effects continued into 1980 , constraining real output growth to a $1-2$ percent rate.

The impact of the sharp rise in energy prices was not distributed equally across all sectors of the economy, but was most severe for those industries and products which were heavy users of energy, such as automobiles. As shown in chart 4 , the relative price of gasoline rose sharply from the end of 1978 through 1980. The retail price of gasoline rose from about 70 cents a gallon at the end of 1978 to $\$ 1.22$ per gallon

7See Keith M. Carlson, "Explaining the Slowdown of 1979: A Supply and Demand Approach," this Review (October 1979), pp. $15-22$

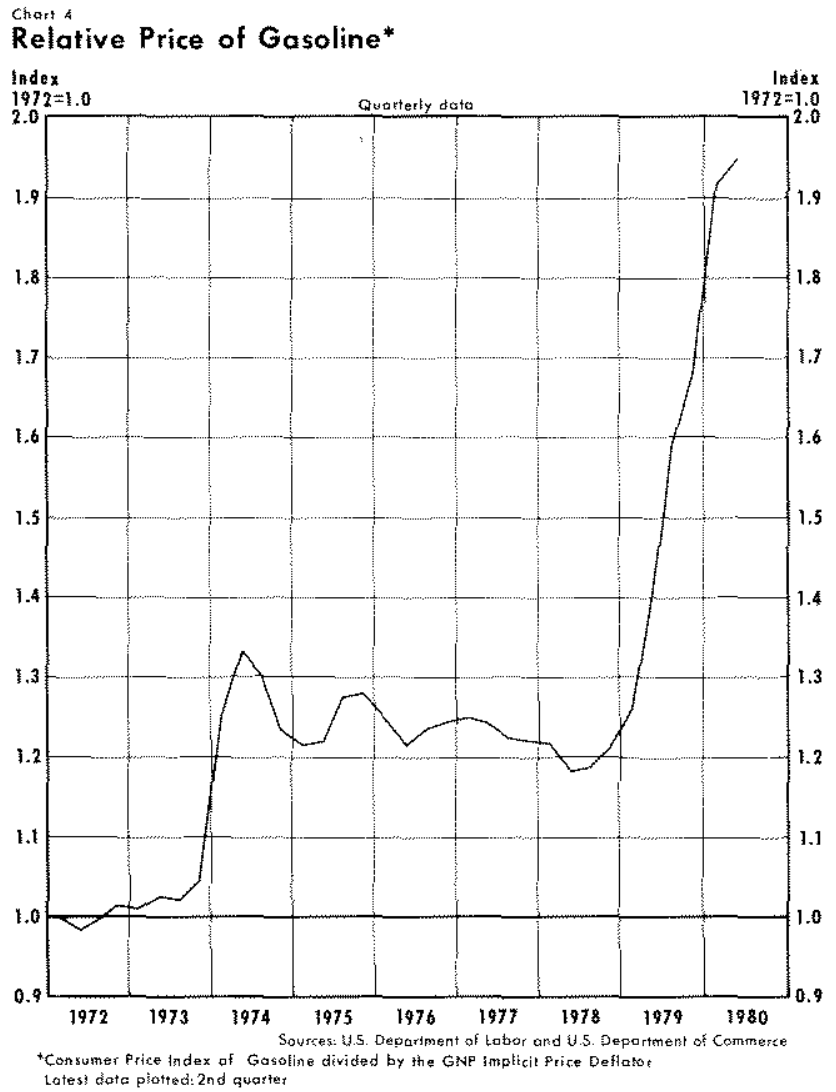


in April 1980. For someone that owned an auto that averaged 10-12 miles per gallon, this rise in the retail price of gasoline increased his annual expenditure on gasoline by about $\$ 700-\$ 800$. This development triggered a general decrease in demand for autos and a shift in preference toward more fuel-efficient imported autos. Consequently, retail sales of domestically produced passenger cars fell dramatically from a rate of about 9 million units at the end of 1978 to a rate of about 7.5 million units at the end of 1979 and then plummeted to a rate of 5.2 million units in May and June of 1980.

\section{Credit Market Developments}

Housing was the other sector of the economy that suffered most severely from developments in the first half of 1980. Housing starts fell from an annual rate of about 1.5 million units at the end of 1979 to an annual rate of approximately 900,000 units in May 1980. The collapse in activity in this market was due primarily to a sharp rise in mortgage costs and greatly reduced availability of mortgage credit. For example, mortgage rates rose from 10.5 percent in April 1979 to 12.9 percent in late 1979 and, finally, to 16.3 percent in April 1980.

The demand for credit, especially short-term credit, surged during the early months of 1980 . In January and February, for example, business loans at commercial banks increased at a 24 percent rate, after rising at only a 6.6 percent rate over the previous three months. Part of this large increase in credit demand resulted from anticipations of a program of selective credit controls. Borrowing that would ordinarily have taken place later in the spring took place early in the year, because potential borrowers were uncertain about their ability to acquire funds at a later date. Consequently, as the Federal Reserve sought to constrain the resulting explosion in money and credit, short-term interest rates soared upward by 3 to 4 percentage points in the span of about two months. The rise in market interest rates resulted in a rapid outflow of savings deposits, which forced savings and loans to hold and acquire deposits by issuing money market certificates that bore much higher interest rates than passbook savings. At the same time, savings and loans were frequently constrained on the mortgage rates they could charge due to ceilings set by usury laws. The consequent sharp rise in mortgage rates and reduced credit flow to the housing market led to the severe drop in housing construction that occurred in early 1980.

\section{Monetary Developments}

Even if monetary stimulus had continued at the rate that prevailed during most of 1979 , the combined effects of the adjustment of the economy to oil price increases, the resulting special structural problems in the auto industry, and the special credit market developments affecting housing would have resulted in a decline in real output in the first half of 1980 . How ever, the degree of monetary stimulus (as measured by growth of money) did change substantially during this period. In October 1979, the growth of M1B began slowing. From October 1979 to February 1980, growth of M1B averaged about 6 percent, compared to its 8.3 percent rate of growth over the first nine months of 1979 . If this reduction in the growth rate of money had continued, it would have exerted a moderate restraining effect on real output growth, adding to the downward pressures being exerted by those factors mentioned above.

Beginning in March of this year, however, monetary stimulus moved from moderately restrictive to very restrictive. For three months, March-May, the money stock declined at an annual rate of approximately 5 percent. Chart 2 helps place this recent reduction in money growth in historical perspective. It shows that the slower than average money growth from September through February was rapidly pulling money growth in line with its trend rate. The following three-month decline in M1B, combined with the previous slowing, plunged it far below its trend rate. As shown in chart 2, when the growth of money slowed so abruptly in the past, real output and employment likewise slowed substantially. In line with this past experience, industrial production fell very sharply after February, growth of employment came to a halt and then declined sharply, and the unemployment rate rose from about 6 percent early in the year to 7.7 percent in May.

\section{Was the First Half of 1980 Unique?}

The events that took place in the first six months of 1980 are not unique, but have become all-too-frequent occurrences. In many aspects, the period from III/79-II/ 80 represents a compressed version of what occurred in the 1973-74 period. ${ }^{8}$ In both periods, the economy was forced to adjust to oil price shocks that resulted in special problems for autos; at the same time, soaring interest rates created special prob-

${ }^{8}$ See Norman N. Bowsher, "Two Stages to the Current Recession," this Review (June 1975), pp. 2-8. 
lems for housing. Monetary developments were also analogous in both periods, although they were somewhat more extended in 1973-74 than in the most recent period. The behavior of real output, employment, and prices was also strikingly similar in both periods. Consequently, a brief comparison of what happened recently to real output, employment, and prices with what happened to these same variables in 1973-74 adds to our understanding of the economic events that occurred in the first half of 1980 .

Although real growth and employment slowed in 1973 and early 1974, these variables did not evidence a sharp decline until monetary stimulus moved from moderately restrictive to sharply restrictive (I/74$\mathrm{I} / 75$ ). Prices also behaved similarly in both periods. In 1973-74, as in the three quarter period ended II/80, prices soared upward, even though the degree of short-run monetary stimulus was markedly reduced.

The behavior of the economy in the first half of 1980 further illustrates that excessive short-run fluctuations in the growth of money in either direction have serious economic implications. In the situation that prevailed from late 1976 through late 1979 , sharp accelerations in money growth increased the trend rate of money growth and, hence, were inconsistent with a policy objective of reducing inflation. Since late 1979 , a sharp deceleration in money growth, combined with supply-side effects that adversely affected real output, caused a severe slowdown in real output. Slow money growth over the three-quarter period ending $\mathrm{H} / 80$ reduced the trend growth of money (the 16- to 20quarter average) by only about 0.5 percent. Although the monetary deceleration had only a minimal effect on inflation, the effect on the growth of real output was large. Consequently, economic events in the last three quarters further support the proposition that pronounced fluctuations of money growth are inconsistent with a policy aimed at progressively reducing inflation while minimizing the contractionary effects on real output.

\section{What Will Happen Now?}

Interpreting what happened to the economy after 1974 is helpful because it gives some indication of what effects alternative monetary developments might have on the economy. The recovery in real output that began in 1975 did not require a very large monetary stimulus. From $I / 75$ to $\mathrm{III} / 76$, growth of M1B averaged 5.5 percent. Real output grew at a rapid pace of 7.5 percent for a year, then slowed to a rate of 3 percent, which was in line with the long-run potential growth rate of real output. Growth of employment was renewed in early 1975 and the unemployment rate began to decline, falling from a peak rate of 9 percent in mid-1975 to 7.5 percent by the end of 1976 .

The sharp surge in the growth of money that started in late 1976 stimulated a renewed growth of real output that lasted through 1978 , with real growth averaging 4.6 percent. However, after 1978, continued monetary stimulus was no longer able to sustain real growth above its longurun potential.

It is also instructive to note that the surge in inflation in 1973-74 that was caused by supply-side shocks to the economy did not last. The economy adjusted to a new higher level of prices, absorbing the energy price increases. Since the growth of money continued at a reduced rate, the rate of inflation fell below a 6 percent rate and this rate was maintained over the next year and a half. Only when the trend rate of growth of money was substantially raised as a result of the persistent 8 percent growth of money that began in late 1976 did inflation again surge upward.

Since May, there has been a very substantial increase in the money stock, offsetting the sharp decline that occurred earlier this year. Such a sharp reversal in the degree of monetary stimulus should act to correct the effects on real output of the earlier decline in money. Consequently, the recent growth of money is consistent with a policy objective of gradu* ally reducing inflation subject to the constraint of not inducing a deep and prolonged recession.

The recent rapid growth of money will become inconsistent with both policy objectives if it is maintained for any prolonged period of time. Most economists expect real growth to remain slow for the next few quarters, as the economy continues to adjust to oil price increases and as special structural problems persist in the automobile and housing industries. Maintaining rapid money growth under these circumstances will add little to real output growth, but will erode the small gains that were made against inflation as a result of the three-quarter reduction in money growth from $111 / 79$ to $11 / 80$. 